\title{
PROBLEMA PENYERAPAN ADAT OLEH PENGADILAN DAN PENGARUHNYA BAGI PEMBARUAN HUKUM PIDANA NASIONAL
}

\author{
Budi Suhariyanto"
}

\author{
Pusat Penelitian dan Pengembangan Hukum dan Peradilan Mahkamah Agung \\ Jalan Jend. A. Yani Kav. 58 Cempaka Putih Timur, Jakarta, 10510
}

\begin{abstract}
The draft of Penal Code Bill regulates the living law in society as a form of extension of legality principle, but in its elucidation, there is no further sufficient explanation about the scope and qualifications of such thing. Thus, there have been some concerns regarding the issue of multi-interpretation in the enforcement of adat criminal law. Having a reflection on the reality of the judges' interpretation in absorbing adat law while deciding the punishment in accordance with the living and developing justice in society, a further and deeper study in jurisprudence is required to reconsider and reformulate the adat criminal law values in the Draft of Criminal Code Bill.
\end{abstract}

Keywords: adat, court, criminal legal update.

\section{Intisari}

Rancangan KUHP mengatur hukum yang hidup dalam masyarakat sebagai bentuk perluasan asas legalitas, tetapi dalam penjelasannya tidak diatur secara definitif tentang ruang lingkup dan kualifikasi yang memadai. Timbul kekhawatiran persoalan multitafsir dalam penegakan hukum pidana adat. Bercermin dari realitas penafsiran hakim yang selama ini ada dalam menyerap hukum adat saat memutuskan pemidanaan sesuai dengan keadilan yang hidup dan berkembang di masyarakat, maka diperlukan kajian yang lebih mendalam terkait yurisprudensi yang ada sebagai pertimbangan melakukan reorientasi dan reformulasi nilai-nilai hukum pidana adat dalam Rancangan KUHP.

Kata Kunci: adat, pengadilan, pembaruan hukum pidana.

\section{Pokok Muatan}

A. Pendahuluan 422

B. Pembahasan 422

1. Eksistensi Hukum Adat dalam Sistem Hukum Pidana Nasional .................................................. 422

2. Praktik Penyerapan Hukum Adat oleh Putusan Pengadilan .................................................... 425

3. Masalah Penyerapan Hukum Adat oleh Putusan Pengadilan dan Pengaruhnya bagi Pembaruan Hukum Pidana Nasional

C. Penutup 


\section{A. Pendahuluan}

Kitab Undang-Undang Hukum Pidana (KUHP) Indonesia yang berlaku saat ini merupakan warisan dari Pemerintah Kolonial Hindia Belanda (Wetboek van Srafrecht). Berbagai upaya untuk memperbaruinya sudah dilakukan sejak lama, namun hingga saat ini tidak kunjung disahkan oleh Dewan Perwakilan Rakyat. Polemik dan kontroversi dari pembahasan pembaruan hukum pidana nasional dalam Rancangan KUHP senantiasa mengemuka meskipun telah berganti tim perumus. Salah satu tema yang cukup intens dipermasalahkan adalah berkaitan dengan pengaturan hukum yang hidup dalam masyarakat (hukum adat), sebagaimana diatur oleh Pasal 2 ayat (1) Rancangan KUHP (Tahun 2015) yang menyebutkan "ketentuan sebagaimana dimaksud dalam Pasal 1 ayat (1) tidak mengurangi berlakunya hukum yang hidup dalam masyarakat yang menentukan bahwa seseorang patut dipidana walaupun perbuatan tersebut tidak diatur dalam peraturan perundang-undangan".

Rancangan KUHP tidak memberikan penjelasan terkait pengertian dan ruang lingkup yang tegas tentang "hukum yang hidup" dan siapa dan bagaimana kriteria yang dimaksud oleh "masyarakat". Adapun Pasal 2 ayat (2) Rancangan KUHP yang menyatakan bahwa "berlakunya hukum yang hidup dalam masyarakat sebagaimana dimaksud pada ayat (1) sepanjang sesuai dengan nilai-nilai yang terkandung dalam Pancasila, hak asasi manusia, dan prinsip-prinsip hukum umum yang diakui oleh masyarakat bangsabangsa," juga dapat menimbulkan disparitas tafsir penegak hukum dan hakim. Selain ketidakjelasan pengaturan, rencana pemberlakuan hukum adat ini dipertentangkan dengan asas legalitas sebagaimana dimaksud Pasal 1 ayat (1) Rancangan KUHP yang menyebutkan "tiada seorang pun dapat dipidana atau dikenakan tindakan, kecuali perbuatan yang dilakukan telah ditetapkan sebagai tindak pidana dalam peraturan perundang-undangan yang berlaku pada saat perbuatan itu dilakukan".

Rencana pembaruan hukum pidana yang menyandingkan asas legalitas dengan pengakuan terhadap hukum yang hidup dalam masyarakat ini bukan tanpa persoalan. Batasan tindak pidana diperluas, tidak saja pada yang tertulis dalam undang-undang tetapi juga menurut hukum (pidana) adat baik yang tertulis maupun tidak tertulis. Dalam konteks ini penyimpangan terhadap asas lex certa sangat mungkin terjadi. ${ }^{1}$ Kemungkinan lain yang akan terjadi adalah dalam praktik penegakan hukum dan putusan pengadilan terkait delik adat dimana selama ini cukup variatif penafsirannya sesuai dengan pluralitas daerah dan adat yang bersangkutan.

Menarik untuk dilakukan pengkajian yang mengemukakan permasalahan bagaimanakah eksistensi hukum pidana adat dan bagaimana pula efektivitasnya dalam putusan-putusan pengadilan? Lalu dapat dipersoalkan juga bagaimanakah formulasi pembaruan hukum pidana nasional yang tepat dalam mendudukan hukum adat sesuai perkembangan hukum yang terjadi khususnya dalam dinamika putusan-putusan pengadilan? Sudah seharusnya praktik penyerapan hukum adat oleh pengadilan selama ini dijadikan sebagai acuan dalam mengadakan pembaruan hukum pidana nasional. Dengan memperhatikan acuan tersebut, diharapkan kebijakan hukum pidana dalam Rancangan KUHP yang mengakomodasi dan menegaskan keberlakuan "hukum yang hidup dalam masyarakat" dapat memberikan penjelasan yang memadai khususnya terkait batasan dan teknis penerapannya.

\section{B. Pembahasan}

\section{Eksistensi Hukum Adat dalam Sistem Hukum Pidana Nasional}

Istilah hukum adat pada awal mulanya dipelopori oleh Snouk Hurgronje yang mencetuskan istilah adatrecht dalam karyanya De Atjhers, yang

I Dewa Made Suartha, "Pergeseran Asas Legalitas Formal ke Formal dan Material dalam Pembaruan Hukum Pidana Nasional", Jurnal Yustisia, Vol. 4, No. 1, Januari-April 2015, hlm.242. 
isinya membahas perihal adat istiadat suku bangsa Aceh. Selanjutnya, penggunaan istilah hukum adat ini ditokohi pula oleh Van Vollenhoven. ${ }^{2}$ Hukum adat diartikan oleh Van Vollenhoven sebagai himpunan peraturan tentang perilaku yang berlaku bagi orang pribumi dan Timur Asing pada satu pihak mempunyai sanksi (karena bersifat hukum), dan pada pihak lain berada dalam keadaan tidak dikodifikasikan (karena adat). ${ }^{3}$

Mengacu pada pengertian hukum adat di atas, menurut Mohd. Din bahwa bangsa Indonesia sudah mempunyai hukum sendiri yang tumbuh dan berkembang dalam kurun waktu yang sudah lama. Pemberlakuan hukum tersebut datangnya dari dalam masyarakat sendiri, bukan berlaku secara paksaan dari luar. ${ }^{4}$ Hal ini terlihat dari berbagai daerah yang masih memberlakukan adat dimana tujuan dari respon masyarakat terhadap terjadinya pelanggaran ketertiban hidup melalui reaksi adat (sanksi adat/obat adat). Penjatuhan sanksi adat (obat adat) hakikatnya menurut Lilik Mulyadi bersifat untuk pemulihan keseimbangan alam magis, pemulihan alam kosmos guna mengembalikan pada keseimbangan yang terganggu agar bersifat religio magis kembali. ${ }^{5}$ Dalam konteks ini, Lilik Mulyadi mengartikan hukum pidana adat sebagai perbuatan yang melanggar perasaan keadilan dan kepatutan yang hidup dalam masyarakat sehingga menimbulkan adanya gangguan ketentraman dan keseimbangan masyarakat yang bersangkutan. ${ }^{6}$

Pada hakikatnya, hukum adat (termasuk hukum pidana adat dan peradilan adat) merupakan kristalisasi nilai-nilai yang hidup di dalam masyarakat yang pengakuannya mendapatkan legitimasi oleh konstitusi khususnya dalam amandemen UUD NRI Tahun 1945 Pasal 18B ayat (2) antara lain menyebutkan bahwa "negara mengakui dan menghormati kesatuankesatuan masyarakat hukum adat dan hak-hak tradisionalnya." Selain itu berdasarkan Pasal 6 ayat (1) Undang-Undang Nomor 39 Tahun 1999 tentang Hak Asasi Manusia diatur bahwa "dalam rangka penegakan hak asasi manusia, perbedaan dan kebutuhan dalam masyarakat hukum adat harus diperhatikan dan dilindungi oleh hukum, masyarakat, dan pemerintah". Berdasarkan realitas teks konstitusi dan undang-undang tentang hak asasi manusia tersebut maka keberadaan masyarakat hukum adat berikut perangkatnya (a quo hukum adat) diakui keberadaannya oleh negara dan bahkan wajib diperhatikan dan dilindungi dalam koridor penegakan hak asasi manusia.

Pada ketetapan MPRS No.II/MPRS/1960 Lampiran A Paragraf 402 memuat garis besar politik bidang hukumyang salah satunya menyatakan bahwa “(a). Asas-asas pembinaan hukum nasional supaya sesuai dengan haluan negara dan berlandaskan pada hukum adat yang tidak menghambat perkembangan masyarakat adil dan makmur". Selanjutnya oleh Pasal 20 ayat (1) Undang-Undang Nomor 19 Tahun 1964 tentang Ketentuan-Ketentuan Pokok Kekuasaan Kehakiman dinyatakan bahwa "hakim sebagai alat revolusi wajib menggali, mengikuti dan memahami nilai-nilai hukum yang hidup dengan mengintegrasikan dari dalam masyarakat guna benar-benar mewujudkan fungsi hukum sebagai pengayoman". Pada perkembangannya mutakhirnya, perubahan ketentuan tentang kewajiban hakim untuk menggali nilai-nilai hukum yang hidup dalam masyarakat semakin dikuatkan oleh Pasal 5 ayat (1) Undang-Undang Nomor 48 Tahun 2009 menentukan bahwa, "Hakim dan Hakim Konstitusi wajib menggali, mengikuti, dan memahami nilai-nilai hukum dan rasa keadilan

\footnotetext{
A Ridwan Halim, 1985, Hukum Adat Dalam Tanya Jawab, Ghalia Indonesia, Jakarta. hlm.10.

Van Vollenhoven, 1983, Orientasi dalam Hukum Adat Indonesia, Jambatan kerjasama dengan Inkultura Foundation Inc, Jakarta, hlm.14 dan lihat Dewi Wulansari, 2016, Hukum Adat Indonesia, Refika Aditama, Bandung, hlm.4.

Mohd. Din, “Aspek Hukum Eksistensi Hukum Pidana Adat”, Makalah, Seminar Penelitian dan Diskusi Terbatas tentang "Eksistensi Hukum Pidana adat di Indonesia: Pengkajian Asas, Teori, Praktik dan Prosedur" di hadapan hakim dari 4 lingkungan peradilan di wilayah Nangroe Aceh Darussalam, 29 Juni 2010, hlm. 2.

Lilik Mulyadi, 2010, Eksistensi Hukum Pidana Adat di Indonesia: Pengkajian Asas, Teori, Norma, Praktik dan Prosedurnya, Laporan Penelitian, Puslitbang Kumdil Mahkamah Agung, Jakarta. hlm. 186.

6 Lilik Mulyadi, 2015, Eksistensi Hukum Pidana Adat, Alumni, Bandung, hlm. 43.
} 
yang hidup dalam masyarakat". Bahkan ditentukan pula larangan bagi hakim jika menolak perkara yang tidak ada hukumnya atau kurang jelas aturannya ${ }^{7}$ sehingga dia harus menemukan hukumnya dengan cara menggali nilai yang hidup dalam masyarakat.

Ketentuan tentang kewajiban hakim dalam menggali hukum yang hidup dalam masyarakat diberlakukan untuk semua perkara, termasuk dalam hukum pidana. Pada praktiknya selama ini para hakim memperhatikan Pasal 5 ayat (3) huruf b Undang-Undang Darurat Nomor 1 Tahun 1951 tentang Tindakan-Tindakan Sementara Untuk Menyelenggarakan Kesatuan Susunan Kekuasaan dan Acara Pengadilan-Pengadilan Sipil (UndangUndang Darurat Nomor 1 Tahun 1951) yang menyatakan "perbuatan yang menurut hukum yang hidup harus dianggap sebagai perbuatan pidana dan yang ada bandingannya dalam KUHP maka perbuatan itu dianggap diancam dengan hukuman yang sama dengan hukuman bandingannya yang paling mirip perbuatan pidana itu."

Memang dalam pandangan positivis, hal ini bertentangan dengan asas legalitas. Pada dasarnya asas legalitas masih harus dipandang perlu eksistensinya dalam sistem Hukum Pidana Indonesia, hal ini disebabkan selain adanya suatu kepastian hukum, juga menghindari adanya suatu bentuk kesewenang-wenangan dari aparatur penegak hukum maupun penguasa dalam konteks yang lebih luas. Dalam konsepsi Negara Hukum, menurut Loebby Loqman bahwa eksistensi asas legalitas adalah primaritas sifatnya, meskipun dinamis waktu menempatkan asas legalitas ini nyatanya memiliki sifat eksepsionalitas terhadap delik adat yang tidak ada padanannya dalam hukum pidana positif. ${ }^{8}$

Pembenaran dari menjadikan hukum (adat) yang hidup tersebut sehingga menjadi sumber hukum pidana Indonesia menurut Mardjono Reksodiputro dapat juga dicari dalam tugas seorang hakim yang berkewajiban mencari keadilan. Untuk upaya ini maka hakim harus menjaga bahwa seseorang yang bersalah melakukan perbuatan yang dicela oleh masyarakat dan patut dipidana memang mendapatkan pidananya. Ukuran perbuatan apa yang "tercela" dan "patut dipidana" dapat ditentukan oleh pembuat undang-undang, tetapi dapat pula didasarkan pada hukum (adat) yang hidup dalam masyarakat yang bersangkutan. ${ }^{9}$ Karena menurut Loebby Loqman, banyak perbuatan-perbuatan yang dikategorikan sebagai tindak pidana adat dan tercela sifatnya, tetapi tidak ada ekuivalensi dalam KUHP, sehingga apabila tetap tidak dihukum terhadap pelakunya tentunya akan menimbulkan rasa ketidakadilan sebagai reaksi adat, keadaan mana mengharuskan hakim untuk menjatuhkan pidana kepada pelakunya, meskipun perbuatannya adalah formil tidak "wederrechtelijk". ${ }^{10}$

Khusus untuk peradilan adat, dalam konteks hukum pidana Indonesia, menurut Eva Achjani Zulfa bahwa keberadaannya menimbulkan dua makna yang melahirkan pertanyaan besar yaitu keberlakuan peradilan adat berarti berlakunya delik adat atau peradilan adat sebagai mekanisme penyelesaian delik (bukan adat) melalui mekanisme peradilan adat. ${ }^{11}$ Dalam konteks ini, Eva Achjani Zulfa lebih lanjut menegaskan bahwa tidak terelakkan permasalahan penerapan hukum adat

Pasal 10 ayat (1) Undang-Undang Nomor 48 Tahun 2009 menyebutkan bahwa, "Pengadilan dilarang menolak untuk memeriksa, mengadili, dan memutus suatu perkara yang diajukan dengan dalih bahwa hukum tidak ada atau kurang jelas, melainkan wajib untuk memeriksa dan mengadilinya", berikutnya ketentuan Pasal 50 ayat (1) menentukan, 'Putusan pengadilan selainharus memuat alasan dan dasar putusan, juga memuat pasal tertentu dari peraturan perundang-undangan yang bersangkutan atau sumber hukum tidak tertulis yang dijadikan dasar untuk mengadili". Pada dasarnya, kalimat, "nilai-nilai hukum dan rasa keadilan yang hidup dalam masyarakat","hukum tidak ada atau kurang jelas", "sumber hukum tidak tertulis yang dijadikan dasar untuk mengadili".

8 Loebby Loqman, "Perkembangan Asas Legalitas dalam Hukum Pidana Indonesia", Makalah, Seminar Asas-Asas Hukum Pidana Nasional yang diselenggarakan oleh Badan Pembinaan Hukum Nasional Departemen Kehakiman dan Hak Asasi Manusia bekerjasama dengan Fakultas Hukum Universitas Diponegoro Semarang di Puri Suite Hotel Ciputra, Semarang, 26-27 April 2004, hlm. 33.

9 Mardjono Reksodiputra, Pembaharuan Hukum Pidana, Pusat Pelayanan Keadilan dan Pengabdian Hukum Universitas Indonesia, Jakarta, hlm. 108 .

10 Loebby Loqman, Op.cit., hlm. 31.

11 Eva Achjani Zulfa, "Eksistensi Peradilan Adat dalam Sistem Hukum Pidana Indonesia", http://bphn.go.id/data/documents/lampiran_ makalah dr. eva achjani, sh.,mh.pdf, hlm. 3-4. 
dan fungsionalisasi lembaga peradilan adat dalam kenyataannya kerap dibenturkan dengan hukum formal $^{12}$

Secara normatif Undang-Undang Darurat Nomor 1 Tahun 1951 mengatur mengenai tindakantindakan sementara dalam menyelenggarakan kesatuan kekuasaan dan acara Pengadil]anPengadilan Sipil. $^{13}$ Ditegaskan didalamnya niat untuk mewujudkan unifikasi, antara lain penghapusan secara berangsur-angsur Pengadilan Swaparaja di daerah-daerah tertentu dan semua Pengadilan Adat. Meskipun Pengadilan Adat sudah dihapuskan dalam aturan perundang-undangan, penelitian yang dilakukan Andi Zainal Abidin menemukan masih adanya Pengadilan Adat yang mengadili perkara adat dan menjatuhkan jenis pidana yang tidak dikenal dalam Pasal 5 UndangUndang Darurat Nomor 1 Tahun 1951 secara eksplisit. Bahkan diantaranya ancaman pidana bagi pembuat kejahatan delik kesusilaan di KUHP dirasakan terlalu ringan dibandingkan dengan sanksi hukum adat pidana dahulu. ${ }^{14}$

Pada dasarnya peradilan adat memainkan peran menjembatani rekonsiliasi dan konsolidasi. Keberadaan peradilan adat atau perdamaian desa telah mendapat pengakuan dalam sistem otonomi daerah, yakni dalam Qanun Aceh Nomor 10 Tahun 2008 tentang Lembaga Adat dan Undang-Undang Nomor 21 Tahun 2001 tentang Otonomi Khusus Bagi Provinsi Papua (Undang-Undang Nomor 21 Tahun 2001). Dalam Undang-Undang Nomor 21 Tahun 2001 diatur adanya dua sistem peradilan di Papua, yaitu peradilan adat dan peradilan negeri.
Pengadilan adat ini memeriksa dan mengadili sengketa perkara perdata adat dan perkara pidana berdasarkan hukum adat. Pengadilan Adat tidak berwenang memeriksa dan mengadili sengketa perdata dan perkara pidana yang salah satu pihak yang bersengketa atau pelaku pidana bukan warga masyarakat hukum adatnya. Pengadilan Adat juga tidak berwenang menjatuhkan hukuman pidana penjara atau kurungan. Putusan Pengadilan Adat mengenai delik pidana yang perkaranya tidak dimintakan pemeriksaan ulang oleh Pengadilan tingkat pertama, menjadi putusan akhir dan berkekuatan hukum tetap. ${ }^{15}$

\section{Praktik Penyerapan Hukum Adat oleh Putusan Pengadilan}

Konsekuensi logis diakui adanya dasar hukum yang tegas eksistensi hukum yang hidup (hukum pidana adat), menurut Lilik Mulyadi akan memberikan tugas, tanggungjawab, dan beban relatif lebih berat kepada hakim untuk lebih dapat memahami dan menggali nilai-nilai hukum yang hidup dalam masyarakat. Hakim harus benarbenar memahami perasaan masyarakat, keadaan masyarakat, terlebih masyarakat Indonesia yang majemuk dengan pelbagai macam adat istiadat, tradisi dan budaya yang berbeda-beda yang tetap dipertahankan sebagai hukum yang hidup. ${ }^{16}$

Hakim menurut fungsinya berwenang bahkan wajib mempertimbangkan apakah aturan hukum adat yang telah ada mengenai soal yang dihadapi masih selaras atau sudah bertentangan dengan kenyataan sosial (sociale werkelijkheid) baru berhubung dengan pertumbuhan situasi

12 Eva Achjani Zulfa, "Keadilan Restoratif dan Revitalisasi Lembaga Adat di Indonesia”, Jurnal Kriminologi Indonesia, Vol. 6 No. II, Agustus 2010, hlm. 183 .

13 Undang-Undang Darurat Nomor 1 Tahun 1951 pada satu sisi telah memberikan dasar legalitas bagi badan peradilan umum untuk mengadili pelanggaran hukum pidana adat. Namun pada sisi yang lain, undang-undang yang sama telah menghapus keberadaan peradilan adat, dan menentukan prosedur penyelesaian perkara pidana pada umumnya untuk disalurkan melalui peradilan umum. dilihat dari sisi hukum acara pidana berdasarkan UU Nomor 8 tahun 1981 tentang Kitab Undang-undang Hukum Acara Pidana (KUHAP), maka ketentuan UndangUndang Darurat Nomor 1 Tahun 1951 sepanjang yang berkaitan dengan aturan mengenai acara pidana sudah dinyatakan dicabut. Demikian pula dengan ketentuan-ketentuan mengenai kekuasaan kehakiman, yang ternyata sudah tidak lagi mengakui badan-badan peradilan di luar badan peradilan Negara. Dengan demikian dapat dikatakan, bahwa eksistensi peradilan adat dewasa ini berada antara ada dan tiada. Di tengah tidak adanya aturan formal yang secara eksplisit mewadahinya, keberadaan peradilan adat adalah sesuatu yang masih dirasakan urgensinya bagi masyarakat adat. Penjelasan lebih lanjut lihat Elwi Danil, "Konstitusionalitas Penerapan Hukum Adat dalam Penyelesaian Perkara Pidana", Jurnal Konstitusi, Vol. 9, No. 3, September 2012, hlm. 590.

14 M. Hatta Ali, 2012, Peradilan Sederhana, Cepat \& Biaya Ringan (Menuju Keadilan Restoratif), Alumni, Bandung. hlm. 191.

15 Ibid., hlm. 352-353.

16 Lilik Mulyadi, Op.cit., hlm. 87. 
baru di dalam masyarakat. Menurut Tolib Setiady bahwa fungsi hakim dalam memeriksa dan mempertimbangkan perkara menurut hukum adat tidak dibatasi undang-undang. Bagi hakim yang penting adalah memperhatikan apakah hukum adat itu masih hidup dan dipertahankan masyarakat adat yang bersangkutan dan apakah hukum adat itu masih patut untuk dipakai sebagai bahan pertimbangan ataukah hukum adat itu sudah tidak sesuai lagi dengan perasaan dan kesadaran hukum masyarakat yang umum, apakah hukum adat itu masih mempunyai kekuatan materiel ataukah malah bertentangan. ${ }^{17}$

Terdapat tiga variasi putusan pengadilan dalam menyikapi keberlakuan hukum adat yaitu: Pertama, pengadilan memutuskan pemidanaan dengan menggunakan padanannya pada KUHP. Misalnya Putusan Mahkamah Agung Nomor 666 K/Pid/1984, tidak menetapkan sanksi adat atas pelanggaran yang dilakukan Terdakwa. Hakim judex factie (Pengadilan Negeri dan Pengadilan Tinggi) dan hakim judex juris (Mahkamah Agung) langsung menetapkan hukuman bagi Terdakwa melalui sanksi pidana. Tegasnya, dengan kata lain sanksi pidana yang dijatuhkan oleh hakim bukan merupakan hukuman pengganti. ${ }^{18}$

Kedua, pengadilan memutuskan membatalkan pemidanaan terhadap terdakwa karena telah diterapkannya peradilan adat oleh Kepala Adat, sebagaimana Putusan Mahkamah Agung Nomor 1644 K/Pid/1988 yang mempertimbangkan bahwa seseorang yang telah melakukan suatu perbuatan, yang menurut hukum yang hidup (hukum adat) di daerah tersebut adalah suatu perbuatan yang melanggar delik adat, Kepala Adat dan para Pemuka Adat memberikan reaksi adat (sanksi adat) terhadap si Pelaku tersebut dan sanksi adat ini telah dilakukan oleh si Terhukum. Terhadap si Terhukum yang telah dijatuhi sanksi adat oleh Kepala Adat tersebut, maka menurut Mahkamah Agung, ia tidak dapat diajukan lagi (untuk kedua kalinya), sebagai Terdakwa dalam persidangan Badan Peradilan Negara (Pengadilan Negeri) dengan dakwaan yang sama. ${ }^{19}$

Ketiga, pengadilan memutuskan pemidanaan dengan menggunakan sanksi pidana adat, sebagaimana Putusan Mahkamah Agung Nomor 854 K/Pid/1983 membatalkan putusan hakim Pengadilan Negeri Klungkung Nomor 33/ Pid.Sumir/1983 yang membebaskan Terdakwa dari semua dakwaan, dakwaan primair (melanggar Pasal 378 KUHP) dan subsidair (melanggar Lokika Sanggraha dari Peswara Bali dan Lombok). Dijelaskan bahwa menurut Yurisprudensi Mahkamah Agung, seorang laki-laki yang terbukti tidur bersama dengan seorang perempuan dalam satu kamar dan pada satu tempat tidur, merupakan bukti petunjuk bahwa laki-laki tersebut telah bersetubuh dengan perempuan itu. Berdasarkan keterangan saksi korban dan bukti petunjuk dari saksi-saksi lainnya maka terbukti bahwa telah bersetubuh dengan saksi korban sebagaimana yang dimaksud dalam dakwaan subsidair. Mengenai dakwaan primair, Mahkamah Agung berpendirian bahwa dakwaan ini tidak terbukti secara sah, karena unsur barang dalam Pasal 378 KUHP tidak terbukti dengan sah dan meyakinkan. Dengan demikian, Terdakwa harus dibebaskan dari dakwaan primair ex Pasal 378 KUHP tersebut. Akan tetapi, Terdakwa bersalah terhadap dakwaan subsidair melakukan tindak pidana adat Lokika Sanggraha.

Ketiga variasi putusan pengadilan a quo Mahkamah Agung di atas pada dasarnya telah melakukan penyerapan hukum pidana adat memiliki konteks pertimbangan yang berbeda. Perbedaan tafsir ini dapat dilihat dari perspektif hakim (aktor) dan perspektif kondisi masyarakat yang melingkupi perkara (faktor) serta filosofi pemidanaan yang hendak dicapai. Pada asasnya, hukum adat yang diakomodasi oleh peradilan umum adalah berkaitan dengan perkara-perkara

\footnotetext{
Tolib Setiady, 2009, Intisari Hukum Adat Indonesia (dalam Kajian Kepustakaan), Alfabeta, Bandung. hlm. 369.

Lilik Mulyadi, Op.cit., hlm. 97-99.

Ibid., hlm. 100-103.
} 
yang tidak ada bandingannya dengan peraturanperaturan yang ada dan menggunakan sanksi seperti hukuman kurungan pengganti atau hukuman denda sebagaimana dimaksud hukum pidana yang dikodifikasikan. ${ }^{20}$ Seperti juga yang diterapkan oleh hakim-hakim Pengadilan Desa merupakan suatu sumber hukum tersendiri untuk peradilan pidana yang keputusannya ${ }^{21}$ mengandung unsur keadilan, kegunaan, dan kepastian hukum diharapkan dapat dirasakan secara langsung bagi masyarakat yang mengharapkan penyelesaian masalah kemasyarakatan dengan cara menjunjung tinggi nilai-nilai kearifan lokal22 ${ }^{22}$ sehingga sifat penyelesaiannya kekeluargaan dan tidak merusak keselarasan hubungan (keluarga) antar suku. ${ }^{23}$

Selain mengadili dan memberikan penilaian bagi pihak-pihak yang berperkara, ada fungsifungsi lain yang harus tercermin dalam putusan hakim peradilan umum yang meliputi fungsi pendidikan hukum bagi masyarakat dan fungsi pembaruan hukum melalui proses penemuan hukum dan penyelesaian konflik secara tuntas. ${ }^{24}$ Betapapun cakapnya legislator, selalu saja memiliki keterbatasan, menyangkut waktu (berlakunya), tempat (berlakunya) dan substansi (pengaturannya). Selalu saja terjadi kesenjangan antara statika norma via a vis dengan dinamika sosial. Apalagi jika terjadi ketidakpuasan masyarakat atas dieterapkannya hukum Negara (yang dibuat oleh legislator) dengan mengesampingkan nilai-nilai hukum dan keadilan yang hidup dalam masyarakat. Maka bukan tidak mungkin, putusan pengadilan tersebut justru akan semakin memperkeruh penyelesaian konflik dan membuat reaksi masyarakat mengarah pada tindakan hukum sendiri (eigenrichting).

Mengatasi kekosongan hukum melalui proses legislasi jelas akan memerlukan proses yang sangat rumit, mahal dan memakan waktu. Situasi tersebut menjadikan kedudukan dan peranan hakim sangatlah penting. Hakim berperan sebagai penafsir, penemu, pencipta sekaligus pemutus dalam suatu perkara hukum. Dalam konteks penerapan hukum adat oleh hakim, mekanisme pendidikan dan sistem mutasi secara nasional yang berpindah dari satu daerah ke daerah lain yang berbeda hukum adatnya secara langsung dan tidak langsung mempengaruhi cara pandang hakim dalam merumuskan putusan pengadilannya. Terkait pula bagaimana para hakim tersebut dapat meyakini pandangan atau opini masyarakat atas keterikatannya terhadap hukum adat yang dimaksud keberlakuannya. Hal ini tentu akan menjadi masalah dalam hal penyerapan hukum adat oleh hakim dalam putusan pengadilannya.

Pada umumnya hakim akan melakukan penelusuran terkait apakah pernah ada yurisprudensi yang berkaitan dengan perkara yang serupa dengan yang ditanganinya. Menurut Ter Haar bahwa apabila tidak ada yurisprudensi atau yurisprudensi yang sudah ada itu sudah tidak sesuai lagi maka hakim harus memutuskan yang menurut keyakinannya

20 Sebagaimana dijelaskan sebelumnya bahwa secara normatif menurut undang-undnag kekuasaan kehakiman bahwa hakim dilarang untuk menolak perkara yang diajukan kepadanya, meskipun tidak ada pengaturannya dalam undang-undang (padanannya) misalnya perkara yang terkait delict adat, sehingga hakim berkewajiban untuk menggali nilai-nilai yang hidup dalam masyarakat untuk memberikan putusan hukum. Dalam konteks ini hakim diberikan kewenangan untuk melakukan upaya penemuan hukum. Jika Hakim tidak diberikan kewenangan untuk melakukan penemuan hukum maka kekosongan hukum yang terjadi akibat tidak sempurnanya undang-undang tersebut akan dapat berubah menjadi kekacauan. Lihat Ansyahrul, 2011, Pemuliaan Peradilan: dari Dimensi Integritas Hakim, Pengawasan, dan Hukum Acara, Mahkamah Agung, Jakarta, hlm. 134. Oleh karenanya dalam melakukan usaha pencapaian terhadap nilai-nilai keadilan, Hakim diberikan keleluasaan untuk melakukan penafsiran-penafsiran, penemuan-penemuan hukum bahkan menurut aliran progresif Hakim dimungkinkan untuk melakukan penciptaan hukum jika kenyataan telah mengharuskan itu (Darmoko Yuti Witanto, et al. 2013, Diskresi Hakim: Sebuah Instrumen Menegakkan Keadilan Substantif dalam Perkara-Perkara Pidana. Alfabeta, Bandung, hlm. 26). Dalam konteks yang demikian, muncul pemikiran yang berpendapat bahwa adil tidaknya suatu undang-undang berada di pundak Hakim (Ahmad Kamil, 2012, Filsafat Kebebasan Hakim, Kencana Prenada Media, Jakarta, hlm. 211). Sehingga Hakim dimungkinkan melakukan pembentukan hukum yang selanjutnya dalam kondisi tertentu (diikuti secara konsisten oleh Hakim lain) dapat dikategorikan sebagai salah satu sumber hukum formil (Budi Suhariyanto, "Eksistensi Pembentukan Hukum oleh Hakim dalam Dinamika Politik Legislasi di Indonesia", Jurnal Rechtsvinding, Vol. 4 No. 3, Desember 2015, hlm. 414).

21 Oemar Seno Adji, 1980, Hukum-Hukum Pidana, Erlangga, Jakarta, hlm. 66.

22 Tedi Sudrajat, “Aspirasi Reformasi Hukum dan Penegakan Hukum Progresif melalui Media Hakim Perdamaian Desa”, Jurnal Dinamika Hukum, Vol. 10 No. 3, September 2010, hlm.299

23 Umi Rozah, 2012, Konstruksi Politik Hukum Mediasi Penal sebagai Alternatif Penyelesaian Sengketa Perkara Pidana, dalam Agustinus Pohan, et al., 2012, Hukum Pidana dalam Perspektif, Larasan, Jakarta, hlm. 309.

24 Pontang Moerad, 2005, Pembentukan Hukum Melalui Putusan Pengadilan Dalam Perkara Pidana, Alumni, Bandung, hlm. 312. 
bahwa hal itu berlaku menurut keadaan dan perkembangan masyarakat. Maka kewajiban hakim di dalam mengadili menurut hukum adat berarti memberikan bentuk terhadap sesuatu yang dibutuhkan sebagai keputusan hukum berdasarkan sistem hukum, kenyataan sosial, dan asas-asas kemanusiaan. ${ }^{25}$

Selanjutnya untuk dapat mengukur sejauh mana aturan-aturan hukum adat itu masih mempunyai kekuatan menurut Tolib Setiady dapat diperhatikan dari: ${ }^{26}$

1) apakah struktur masyarakat adatnya masih tetap dipertahankan ataukah sudah berubah;

2) apakah kepala adat dan perangkat hukum adatnya masih tetap berperan sebagai petugas hukum adat;

3) apakah masih sering terjadi penyelesaian perkara dengan keputusan-keputusan serupa;

4) apakah kaidah-kaidah hukum adat yang formal masih dipertahankan ataukah sudah bergeser dan berubah; dan

5) apakah hukum adat itu tidak bertentangan dengan Pancasila dan UUD 1945 serta politik hukum nasional.

Menurut M. Misbahul Mujib bahwa eksistensi hukum Adat pada masa sekarang jelas akan lebih banyak bergantung pada hukum tertulis termasuk konstitusi dan lain-lain peraturan perundang-undangan. Secara historis hubungan interdepensi ini merupakan implikasi dari resepsi sistem hukum Belanda dalam sistem hukum Indonesia, pemerintahan Belanda menerapkan asas konkordansi atas hukum-hukumya di Indonesia. delik adat dianggap berlaku atau bersifat hukum, tidaklah tergantung pada peraturan perundangundangan melainkan pada tindakan-tindakan yang oleh adat oleh masyarakat dianggap patut dan mengikat. Disamping itu pula para penduduk memiliki keyakiinan yang sama yang menyatakan bahwa peraturan adat harus dipertahankan oleh kepala adat dan petugas lainnya. ${ }^{27}$

\section{Masalah Penyerapan Hukum Adat oleh Putusan Pengadilan dan Pengaruhnya bagi Pembaruan Hukum Pidana Nasional \\ Pada dasarnya Pasal 2 ayat 1 RUU} KUHP yang mengakomodasi hukum adat, tidak memberikan pengertian yang sangat jelas mengenai apa yang dimaksud dengan "hukum yang hidup dalam masyarakat". Apabila dianggap sebagai suatu pengakuan mengenai eksistensi hukum yang hidup dalam masyarakat, maka menurut Supriyadi Widodo Eddyono dkk bahwa RUU KUHP tidak memberikan batasan yang jelas mengenai hukum yang mana yang diterapkan, mengingat bahwa setiap komunitas mempunyai hukum yang berbeda-beda antara satu dengan yang lainnya. Apabila dalam hukum yang hidup dalam masyarakat itu tercakup juga hukum adat, RUU KUHP tidak menentukan dengan jelas siapa yang dimaksud dengan masyarakat adat, tidak ada batasan-batasan yang pasti dan rinci. Hal ini menjadikan setiap orang bisa saja menganggap dirinya sebagai masyarakat adat sehingga ia dapat menolak atau mengubah ketentuan hukum yang seharusnya berlaku baginya. ${ }^{28}$

Pasal 2 ayat (2) RUU KUHP yang menyatakan bahwa "berlakunya hukum yang hidup dalam masyarakat sebagaimana dimaksud pada ayat (1) sepanjang sesuai dengan nilai-nilai yang terkandung dalam Pancasila, hak asasi manusia, dan prinsip-prinsip hukum umum yang diakui oleh masyarakat bangsa-bangsa", menurut Supriyadi Widodo Eddyono dkk juga masih mengandung

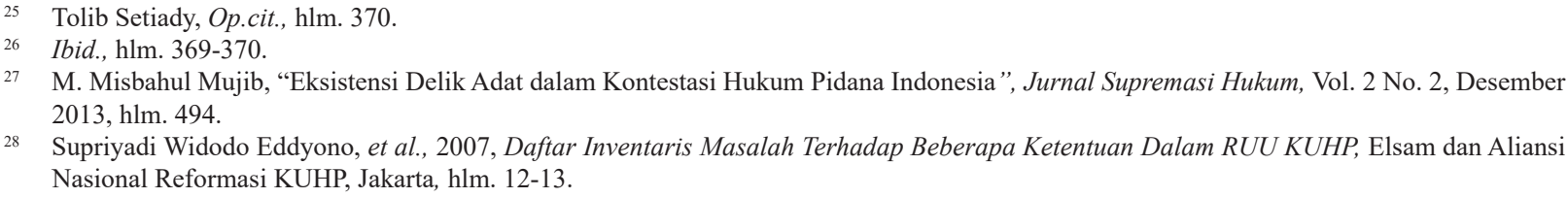

28 Supriyadi Widodo Eddyono, et al., 2007, Daftar Inventaris Masalah Terhadap Beberapa Ketentuan Dalam RUU KUHP, Elsam dan Aliansi Nasional Reformasi KUHP, Jakarta, hlm. 12-13. 
multi interpretasi dan tidak jelas. Ketidakjelasan ini akan berakibat penggunaan hukum yang hidup dalam masyarakat secara semena-mena. ${ }^{29}$ Selain itu, menurut Sudargo Gautama dapat dipersoalkan adanya daerah-daerah hukum adat yang berbeda hingga apabila seseorang hidup sehari-hari di bawah hukum adat dari lingkungan hukum adat, kemudian mengadakan hubungan dengan orang dari lingkungan adat lain, maka menimbulkan persoalan hukum antar adat. ${ }^{30}$

Era reformasi telah memberikan legitimasi bagi perkembangan kebijakan hukum yang bersifat otonomi daerah. Masing-masing daerah yang memiliki karakteristik budaya kuat diberikan kelonggaran dalam mengekspresikan eksistensi hukum yang hidup dalam masyarakatnya. Diantara hukum yang hidup tersebut sebagian ada yang diformulasikan dalam bentuk peraturan Gubernur atau Kepala Daerah dan sebagian lainnya tetap berada pada peraturan parsial komunitas adat atau peradilan adat. Masing-masing bentuk pengaturan formal dan nonformal tersebut memiliki mekanisme pelaksanaan dan konsekuensi hukum yang berbeda.

Bagi yang diformalkan dalam Peraturan Gubernur atau Kepala Daerah maka pelaksanaannya dikawal oleh aparatur pemerintah a quo penegak hukum dan pengadilan serta Pemuka Adat setempat. Misalnya, penerapan peraturan hukum pidana Islam (jinayah) di daerah Pemerintahan Provinsi Aceh yang mana penegakannya didukung oleh Mahkamah Syariah. Demikian halnya dengan penerapan otonomi khusus di daerah Pemerintah Provinsi Papua yang memberikan legitimasi kepada peradilan adat dan peradilan umum menangani sengketa perdata dan pidana adat. Dalam konteks ini tidak cukup bermasalah dalam hal mengikatnya terhadap masyarakat adat atau daerah setempat, karena perangkat peraturannya berbentuk tertulis dan formal ditegakkan oleh Pemerintah bersama otoritas adat. Adapun bagi yang belum atau tidak ada hukum adat yang dapat berlaku di seluruh diformalkan dalam peraturan pemerintahan daerah, kedudukannya berada pada otoritas perkumpulan kelompok adat atau agama yang bersifat mengikat bagi segenap anggota dan/atau pemeluknya. Tidak ada konsekuensi hukum dalam fungsionalisasi peraturan tidak formal dari masyarakat adat tersebut bagi penegak hukum atau pengadilan karena bersifat tidak tertulis dan menyimpangi dari asas legalitas. Menurut Supriyadi Widodo Eddyono dkk bahwa jika hukum yang hidup dalam masyarakat ini diajukan ke pengadilan, maka jaksa (penuntut umum) akan menghadapi hambatan di dalam merumuskan delik dalam surat dakwaan. Elements of crime yang terdapat pada hukum yang hidup dalam masyarakat tidak begitu rinci seperti halnya ketentuan pidana dalam peraturan perundang-undangan. Persoalan lainnya adalah mengenai proses dan cara memeriksa perkara jika pelaku pelanggaran bukan kelompok persekutuan masyarakat hukum adat yang bersangkutan. ${ }^{31}$

Seiring dengan perkembangan transportasi dan teknologi informasi telah mendorong perubahan pola interaksi antarmasyarakat di mana terbuka peluang pergeseran dari homogenitas menuju heterogenitas sehingga dalam sebuah daerah tidak hanya didominasi oleh suatu kelompok masyarakat hukum adat tertentu. Implikasinya, jika terjadi konflik atau pelanggaran yang melibatkan pelaku atau korban yang bukan dari kelompok persekutuan masyarakat hukum adat yang bersangkutan maka mekanisme penyelesaian konfliknya tentu tidak hanya bisa disalurkan melalui satu pilihan hukum adat tertentu, tetapi bisa jadi diselesaikan melalui mekanisme hukum yang lebih netral yaitu peradilan negara menjadi alternatif pilihan. Dalam konteks ini pengadilan dilarang menolak perkara yang demikian.

Hilman Hadikusumo mengingatkan bahwa lapangan berlakunya hukum adat terbatas pada lingkungan masyarakat adat tertentu, tidak 
Indonesia. Tetapi, apakah hukum adat setempat itu masih berlaku?, selama masyarakat hukum adat itu ada, maka selama itu hukum adat akan tetap berlaku. Hanya sejauh mana kekuatan berlakunya tergantung pada keadaan waktu dan tempat. Terhadap siapa berlakunya hukum adat, ia berlaku terhadap anggota-anggota masyarakat adat dan orang-orang di luarnya yang terkait akibat hukumnya. ${ }^{32}$ Selanjutnya mengemuka pertanyaan sebagaimana diajukan oleh Bushar Muhammad yaitu bagaimana hakim dapat menentukan bahwa sesuatu perbuatan bertentangan dengan hukum adat, padahal hukum adat adalah serangkaian peraturan yang tidak tertulis, jadi tidak mengenal sistem prae existenteregels. Menurut hukum adat suatu perbuatan yang semula tidak dilarang, pada suatu saat dapat merupakan delik adat. Dengan demikian jika suatu waktu petugas adat menganggap bahwa perbuatan itu memperkosa keselamatan masyarakat maka perbuatan tersebut merupakan delik. ${ }^{33}$

Berkaitan dengan realitas di atas, Artidjo Alkostar mengatakan bahwa elastisitas dan kekenyalan dari eksistensi hukum adat dapat diandalkan. Esensi hukum adat yang fleksibel dan "tahan banting" demikian, pada saat yang bersamaan merupakan keunggulan dari hukum adat untuk eksis dalam masyarakat dengan penampilan yang selalu relevan dan responsif. Hanya saja, keunggulan dan kelebihan hukum adat sebagaimana tersebut tidak selalu disadari oleh masyarakat pemakai hukum adat itu sendiri. Bahkan ada sebagian masyarakat yang melecehkan keberadaan hukum adat. Hal demikian bisa terjadi karena persepsi mereka tentang hukum adat. Keadaan yang demikian pada gilirannya akan membuat masyarakat pendukung hukum adat merasa tidak sanggup membuat antisipasi ke masa depan tentang relevansi hukum adat. ${ }^{34}$

Dibutuhkan hakim yang mengerti dengan baik karakteristik hukum adat yang akan dijadikan dasar putusannya. Seringkali timbul pertanyaan mendasar yaitu bagaimana hakim dapat menentukan bahwa sesuatu perbuatan bertentangan dengan hukum adat, padahal hukum adat adalah serangkaian peraturan yang tidak tertulis. Di dalam hukum adat suatu perbuatan yang semula tidak dilarang, pada suatu saat dapat merupakan delik. Perubahan atau pembaruan suatu delik adat ini akan mengikuti perkembangan reaksi masyarakat terhadap ancaman atau kerusakan keseimbangan yang harus segera dipulihkan secara cepat.

Secara de facto, "hukum yang hidup dalam masyarakat" yang masih dianut oleh kelompok masyarakat adat, akan menjadi pertimbangan bagi hakim bilamana tidak ditemukan padanannya dalam KUHP. Apalagi dari otoritas atau tokoh kelompok adat tersebut dituntutkan dan didorong keberlakuan mengikatnya. Menurut Anto Soemarman bahwa otoritas tokoh-tokoh hukum adat, seperti pemangku adat, kelianggama, dan pemuka-pemuka masyarakat, merupakan salah satu indikator hukum adat. Otoritas tokoh-tokoh hukum adat yang diakui oleh masyarakat mempunyai pengaruh terhadap putusan hakim di ikarenakan beberapa alasan, diantaranya: ${ }^{35}$

1) Tokoh-tokoh hukum adat menjadi semacam konsultan bagi hakim-hakim ketika akan memutus perkara, terutama bila perkara itu menyangkut delik adat;

2) Tokoh-tokoh hukum adat sering dijadikan saksi ahli dalam sidang-sidang peradilan;

3) Apa yang dialami oleh tokohtokoh hukum adat merupakan suatu pelestarian nilai-nilai hukum adat, yang selalu diperlihara dari generasi kegenerasi sehingga karenanya hukum adat juga berwujud personifikasi tokoh-tokoh hukum adat; dan

4) Dalam kenyataannya

\footnotetext{
Hilman Hadikusumo, 1989, Hukum Pidana Adat, Alumni, Bandung hlm. 18-19.

Bushar Muhammad, 2006, Pokok-Pokok Hukum Adat, Pradnya Paramita, Jakarta hlm. 74.

Anto Soemarman, 2003, Hukum Adat: Perspektif Sekarang dan Mendatang, Adicita Karya Nusa, Yogyakarta hlm. 120.

Anto Soemarman, Op.cit., hlm.107.
} 


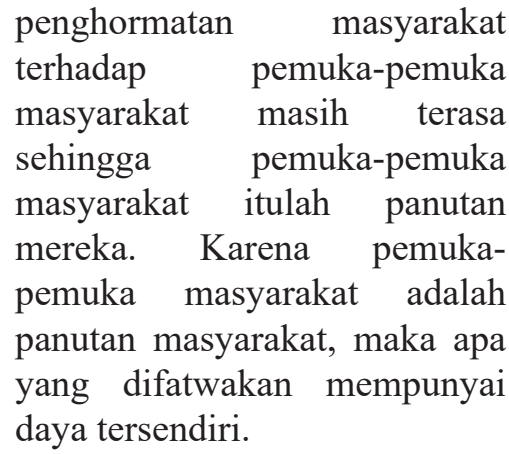

Pada daerah yang peradilan adatnya masih ada dan perannya diakui oleh masyarakat setempat, hakim cenderung untuk mempertimbangkan keberlakuannya untuk memutuskan penghapusan pemidanaan terhadap para pelaku pelanggar yang telah dikenakan pidana adat oleh peradilan adat tersebut. Namun akan berbeda untuk kelompok masyarakat adat yang tidak mempunyai atau menuangkan "hukum yang hidup dalam masyarakatnya" dalam bentuk tertulis, tentu akan menjadi tantangan bagi hakim memilih dan memilahnya untuk diterapkan dan diserap dalam putusan pengadilannya. Lebih sulit lagi jika ternyata terjadi pergolakan keberlakuan antara perspektif otoritas Pemuka Adat dengan keterikatan masyarakat adat yang berkembang dan mulai melonggar kepatuhannya. Tidak ada sebuah standar khusus dalam penerapan hukum pidana adat dari Mahkamah Agung (sebagai lembaga peradilan tertinggi) sehingga diserahkan sepenuhnya pada penilaian subjektif para hakim.

Dari perspektif asas dan praktiknya melalui yurisprudensi Mahkamah Agung, hukum pidana adat dan peradilan adat masih diakui eksistensinya sesuai dengan kadar keterikatan masyarakat setempat terhadapnya. Meskipun dalam perkara tertentu terdapat perbedaan pendapat dari pengadilan yang menangani dimana sebagian menerapkan pemidanaan dengan disandarkan pada KUHP ataupun penerapan sanksi pidana adat setempat. Namun demikian dari berbagai putusan pengadilan yang ada, tampak sekali eksistensi dan keberlakuan hukum pidana adat sangat berarti dan dibutuhkan untuk mengembalikan harmonisasi sosial dan penyelesaian konflik yang ada. Kearifan putusan peradilan pidana yang mengakomodasi hukum adat dan peradilan adat hendaknya dijadikan bahan dasar reorientasi dan reformulasi asas legalitas dalam pembaruan hukum pidana nasional.

Sebagaimana Utrecht keberatan dengan dianutnya asas (legalitas) tersebut di Indonesia. Alasannya ialah banyak sekali perbuatan yang sepatutnya dipidana (strafwaardig) tidak dipidana karena adanya asas tersebut. Begitu pula asas tersebut menghalangi berlakunya hukum pidana adat yang masih hidup dan akan hidup. ${ }^{36}$ Perspektif pembangunan kedaulatan hukum nasional dalam pembaruan hukum pidana seharusnya tidak memberangus atau mencerabut hakikat keberagaman hukum adat yang telah diakui eksistensinya oleh putusan pengadilan tersebut, baik tertulis dalam kesepakatan para Pemangku Adat maupun bentuknya tak terltulis dan sebatas kebiasaan yang mengikat. Namun demikian, pengaturan tentang hukum yang hidup dalam masyarakat juga tidak boleh diformulasikan secara sumir (tidak jelas) sehingga berpotensi membuka peluang untuk menerapkannya secara sewenangwenang dengan alasan multi tafsir.

Menurut Marco Manarisip bahwa subtansi hukum adat tidaklah sekompleks dengan hukum modern sehinggga dalam merumuskannya secara tertulis memang menjadi kesulitan sekarang ini yang terjadi di Indonesia, apalagi membuat dalam satu kodifikasi. ${ }^{37}$ Andi Hamzah juga menjelaskan hal yang senada yaitu tidak mungkin dikodifikasi seluruhnya karena perbedaan antar adat pelbagai suku bangsa, tetapi dilihat dari segi lain, yaitu kepastian hukum dan perlindungan terhadap hak asasi manusia dari perlakuan yang tidak wajar dan tidak adil dari penguasa dan hakim. Lagipula

\footnotetext{
Loebby Loqman, Op.cit., hlm. 9.

37 Marco Manarisip, "Eksistensi Pidana Adat dalam Hukum Nasional", Jurnal Lex Crimen, Vo. 1 No. 4, Oktober-Desember 2012 , hlm. 39.

38 Danel Aditia Situngkir, “Asas Legalitas dalam Hukum Pidana Nasional dan Hukum Pidana Internasional”, Soematera Law Review, Vol. 1, No. 1, 2018, hlm. 29.
} 
sebagai Negara berkembang yang pengalaman dan pengetahuan para hakim masih sering dipandang kurang sempurna. ${ }^{38}$

Perlu ada batasan tentang makna "hukum yang hidup" tersebut, apakah diharuskan tertulis (dalam sebuah keputusan adat) dan penerapannya dikehendaki oleh otoritas adat? Ataukah meliputi yang tidak tertulis, dimana penerapannya digantungkan pada opini dari Pemuka dan masyarakat Hukum Adat? Demikian halnya dengan kategorisasi "masyarakat" (yang menghidupkan hukum adat) tersebut harus pula dijelaskan dalam Rancangan KUHP. Selain itu, diperlukan penjelasan khusus dalam Rancangan KUHP mengenai definisi dan ruang lingkup serta kategorisasi masyarakat hukum adat yang dimaksudkan oleh Pasal 2 ayat (1).

Berkaitan dengan definisi yang dimaksud masyarakat hukum adat dapat mengakomodasi Pasal 1 ayat (3) Peraturan Kepala Badan Pertanahan Nasional Nomor 5 Tahun 1999 tentang Pedoman Penyelesaian Masalah Hak Ulayat Masyarakat Hukum Adat yaitu sekelompok orang yang terikat oleh tatanan hukum adatnya sebagai warga bersama suatu persekutuan hukum karena kesamaan tempat tinggal ataupun atas dasar keturunan. Dengan definisi ini dapat dijelaskan ruang lingkup pengertian masyarakat hukum adat, diantaranya harus ada sekelompok orang yang terikat dengan tatanan hukum adatnya. Dalam hal ini tidak dibatasi hukum adat yang berbentuk tertulis saja, tetapi apa yang ditetapkan secara bersama dan menjadi kebiasaan juga termasuk. Unsur kerterikatan ini menjadi fondasi utama dari eksistensi hukum yang hidup dalam masyarakat itu, dengan demikian dapat dipahami oleh hakim sebagai ungkapan perasaan atau nilai keadilan yang harus ditegakkan.

Penegasan dalam definisi yang mengungkap unsur persekutuan hukum karena kesamaan tempat tinggal ataupun dasar keturunan, akan menjadi acuan untuk menetapkan kategorisasi masyarakat adat. Diantaranya memang ada yang ditentukan oleh wilayah tempat tinggal, sehingga menjadi batasan pula atas keberlakuan hukum pidana adatnya. Hal ini merupakan sebuah keniscayaan, sehingga terhadap daerah yang berbeda maka masyarakat hukum adatnya memiliki reaksi yang berbeda. Semisal menurut Hilman Hadikusumo bahwa di Bali, pria dan wanita boleh saja mandi telanjang bulat bersama-sama dalam satu tempat pemandian dan tidak akan timbul reaksi atau koreksi dari masyarakat adat Bali. Tetapi jika hal itu dilakukan di tempat pemandian orang Lampung misalnya, maka akan timbul reaksi dari masyarakat dan dapat berakibat semua yang mandi telanjang itu dan kerabatnya dikenakan sanksi hukuman adat. ${ }^{39}$

Selain itu Rancangan KUHP juga perlu mengatur secara khusus terkait harmonisasi dan singkronisai penegakan hukum pidana adat, sehingga dapat memberikan pedoman bagi aparatur penegak hukum dan hakim dalam pelaksanaannya. Misalnya jika sudah diputuskan oleh peradilan adat, maka apakah masih perlu diproses oleh penegak hukum dan dibawa ke peradilan umum sehingga masih berlakukan asas nebis in idem? Bagaimana juga status pelaksanaan putusan adat tersebut, jika masih harus diputuskan pemidanaannya oleh hakim peradilan umum, maka bukankah ini juga akan tidak adil bagi Pelaku yaitu mendapatkan hukuman pidana dua kali?

Rancangan KUHP (2015) belum memberikan penegasan terhadap hal-hal di atas. Memang didalamnya sudah mengakomodasi filosofi pemidanaan yang bersifat memulihkan keseimbangan masyarakat (Pasal 55 ayat (1) huruf c), pedoman pemidanaan yang mewajibkan mempertimbangkan pandangan masyarakat (Pasal 56 ayat (1) huruf k), pemenuhan kewajiban adat setempat sebagai pidana tambahan (Pasal 68 ayat (1) huruf e), dan menjadi pidana pokok jika memenuhi ketentuan Pasal 2 ayat (1), (Pasal 102 ayat (2)) serta dijadikan acuan dalam alasan dasar meringankan (Pasal 139

39 Hilman Hadikusumo, Op.cit., hlm. 10. 
hurufh) dan memberatkan hukuman (Pasal 141 huruf i). Secara eksplisit Rancangan KUHP memberikan kewenangan memeriksa kembali perkara pidana adat yang berpadanan dengan KUHP, proses dan penghukuman yang diselenggarakan oleh peradilan adat ataupun berbentuk reaksi masyarakat adat hanya sebatas digunakan sebagai dasar peringan.

Seharusnya tidak sebatas itu saja, merujuk pada yurisprudensi Mahkamah Agung (sebagaimana diuraikan sebelumnya), terhadap Pelaku yang sudah diadili dengan hukum pidana adat oleh otoritas adat maka tidak perlu lagi dijatuhi hukuman kembali. Meskipun sanksi pidana dari Pengadilan Negara adalah ringan, tetapi akan lebih baik jika dihapuskan pemidanaannya (dilepaskan dari segala tuntutan hukum). Lebih jauh lagi, bagi perkara pidana yang sudah melalui proses pemidanaan adat, maka terhadapnya perlu diatur dan ditegaskan untuk tidak diperlukan lagi penuntutan oleh penegak hukum. Garansi terhadap hal ini perlu ditegaskan dalam penetapan hakim, sehingga suatu saat tidak dipermasalahkan kembali karena pada dasarnya dari pihak korban tidak lagi menghendakinya dan di sisi lain keseimbangan masyarakat telah terpulihkan. Akan menjadi masalah dan goncangan baru jika diproses kembali berdasarkan otoritas hukum Negara.

Sebagaimana diketahui bahwa sistem peradilan pidana saat ini dapat dianggap tidak mewakili kepada kepentingan korban. ${ }^{40}$ Jaksa sebagai penuntut umum menurut Faizal Adi Surya tidak dianggap mewakili kepentingan korban, hanya dianggap mewakili kepentingan Negara. Sistem peradilan menutup kemungkinan bagi korban untuk menuntut. Faktor inilah yang menyebabkan penyelesain perkara tidak dimungkinakn diselesaikan menjadi dialog dan konsesi antara pelaku dan korban, meskipun keduanya adalah pihak yang berkepentingan dalam perkara ini. Dan keduanya tetap memiliki harapan, untuk mencari hasil yang lebih memuaskan daripada melalui mekanisme formal atau melalui peradilan. ${ }^{41}$ Jadi konflik ini menurut Ahmadi Hasan harus diarahkan pada harmonisasi atau kerukunan dalam masyarakat serta tidak memperuncing keadaan, dengan sedapat mungkin menjaga suasana perdamaian. ${ }^{42}$

Sistem pemidanaan selama ini (KUHP) yang bersifat individualistik dan formal prosedural sesungguhnya telah mengabaikan realitas nilai perdamaian (sebagaimana terdapat dalam kaidah hukum pidana adat) sehingga tidak dijadikan sebagai dasar penghapusan pemidanaan. Menurut Budi Suhariyanto bahwa kepentingan Negara dalam penyelesaian perkara pidana sangat besar dan kuat untuk memidana kendati antara Pelaku dan Korban telah berdamai (secara adat). Seolah-olah Negara akan bersalah jika Pelaku yang telah dimaafkan dan mengganti kerugian Korban dihapuskan pemidanaannya. Selama ini KUHP kurang mengindahkan keberadaan dan penerapan filosofi musyawarah mufakat (berdasarkan Pancasila) dalam perdamaian sebagai asas penyelesaian konflik antar warga masyarakat, baik yang bersifat individual maupun ketertiban umum. Jika filosofi pemidanaan yang abai akan perdamaian (secara adat) dibiarkan berlarut-larut maka dikhawatirkan budaya hukum dalam masyarakat. ${ }^{43}$

\section{Penutup}

Hukum pidana adat dan peradilan adat masih diakui eksistensinya oleh hakim peradilan umum sesuai dengan kadar keterikatan masyarakat terhadapnya. Meskipun dalam perkara tertentu terdapat perbedaan pendapat dari pengadilan yang menangani, dimana sebagian menerapkan pemidanaan dengan disandarkan pada KUHP

40 Rena Yulianti, "Melihat Kembali Keberadaan Korban dalam Sistem Peradilan Pidana”, dalam Syaiful Bakhri, et al., 2014, Hukum Pidana Masa Kini, Total Media, Yogyakarta, hlm. 163.

41 Faizal Adi Surya, "Tinjauan Mediasi Penal dalam Perspektif Hukum Adat dan Hukum Islam”, Jurnal Jurisprudence, Vol. 5 No.2, September 2015, hlm. 118.

42 Ahmadi Hasan, "Penyelesaian Sengketa Melalui Upaya (Non-Litigasi) Menurut Peraturan Perundang-Undangan", Jurnal Al-Banjari, Vol. 5, No. 9, Januari-Juni 2007, hlm. 5.

43 Budi Suhariyanto, "Kedudukan Perdamaian Sebagai Penghapus Pemidanaan Guna Mewujudkan Keadilan Dalam Pembaruan Hukum Pidana", Jurnal Rechtsvinding, Vol. 5, No. 1, April 2017, hlm. 2. 
dan lainnya menggunakan pidana adat setempat. Kearifan putusan pengadilan yang mengakomodasi hukum pidana adat dan peradilan adat, hendaknya dijadikan bahan dasar reorientasi dan reformulasi asas legalitas. Sudah seharusnya praktik penyerapan hukum adat oleh pengadilan selama ini dijadikan sebagai acuan dalam mengadakan pembaruan hukum pidana nasional.

Pasal 2 ayat 1 RUU KUHP telah mengakomodasi hukum adat, tetapi tidak terdapat didalamnya penjelasan yang memadai mengenai pengertian "hukum yang hidup dalam masyarakat". Diperlukan penjelasan khusus dalam Rancangan KUHP mengenai definisi dan ruang lingkup serta kategorisasi masyarakat hukum adat yang dimaksudkan oleh Pasal 2 ayat (1). Pihak legislator kiranya perlu mencermati pengalaman penyerapan hukum adat yang dilakukan oleh putusan pengadilan dimana keberadaannya cukup variatif dalam memutuskan pemidanaan yaitu berdasarkan keterikatan masyarakat dan tingkat pengaruh otoritas tokoh adat setempat, sehingga jika tidak dijelaskan secara eksplisit maka dikhawatirkan akan banyak terjadi disparitas putusan pemidanaan terkait penegakan hukum adat.

Selain itu, merujuk pada yurisprudensi Mahkamah Agung, terhadap Pelaku yang sudah diadili dengan hukum pidana adat oleh otoritas adat, maka tidak perlu lagi dilakukan penuntutan serta dijatuhi pidana oleh pengadilan. Secara eksplisit Rancangan KUHP memberikan kewenangan memeriksa kembali perkara pidana adat yang berpadanan dengan KUHP, namun proses dan penghukuman yang diselenggarakan oleh peradilan adat ataupun berbentuk reaksi masyarakat adat hanya sebatas digunakan sebagai dasar peringan dan bukan penghapusan pemidanaan sebagaimana yang dianut oleh Mahkamah Agung melalui yurisprudensinya saat menyerap hukum pidana adat secara in concreto.

\section{DAFTAR PUSTAKA}

\section{A. Buku}

Ansyahrul, 2011, Pemuliaan Peradilan: dari Dimensi Integritas Hakim, Pengawasan, dan Hukum Acara, Mahkamah Agung, Jakarta.

Eddyono, Supriyadi Widodo, et al., 2007, Daftar Inventaris Masalah Terhadap Beberapa Ketentuan Dalam RUU KUHP, Elsam dan Aliansi Nasional Reformasi KUHP, Jakarta. Gautama, Sudargo, 1977, Hukum Antar Tata Hukum (Kumpulan Karangan), Alumni, Bandung. Hadikusumo, Hilman, 1989, Hukum Pidana Adat, Alumni, Bandung.

Halim, A Ridwan, 1985, Hukum Adat Dalam Tanya Jawab, Ghalia Indonesia, Jakarta.

Kamil, Ahmad, 2012, Filsafat Kebebasan Hakim, Kencana Prenada Media, Jakarta.

Moerad, Pontang, 2005, Pembentukan Hukum Melalui Putusan Pengadilan Dalam Perkara Pidana, Alumni, Bandung.
Muhammad, Bushar, 2006, Pokok-Pokok Hukum Adat, Pradnya Paramita, Jakarta.

Mulyadi, Lilik, 2015, Eksistensi Hukum Pidana Adat, Alumni, Bandung.

Reksodiputra, Mardjono, Pembaharuan Hukum Pidana, Pusat Pelayanan Keadilan dan Pengabdian Hukum Universitas Indonesia, Jakarta.

Rozah, Umi, "Konstruksi Politik Hukum Mediasi Penal sebagai Alternatif Penyelesaian Sengketa Perkara Pidana", dalam Agustinus Pohan, et al., 2012, Hukum Pidana dalam Perspektif, Larasan, Jakarta.

Setiady, Tolib, 2009, Intisari Hukum Adat Indonesia (dalam Kajian Kepustakaan), Alfabeta, Bandung.

Seno Adji, Oemar 1980, Hukum-Hukum Pidana, Erlangga, Jakarta. 
Soemarman, Anto, 2003, Hukum Adat: Perspektif

Sekarang dan Mendatang, Adicita Karya Nusa, Yogyakarta.

Vollenhoven, Van, 1983, Orientasi dalam Hukum Adat Indonesia, Jambatan kerjasama dengan Inkultura Foundation Inc, Jakarta.

Yulianti, Rena, "Melihat Kembali Keberadaan Korban dalam Sistem Peradilan Pidana", dalam Syaiful Bakhri, et al., 2014, Hukum Pidana Masa Kini, Total Media, Yogyakarta. Witanto, Yuti, et al., 2013, Diskresi Hakim: Sebuah Instrumen Menegakkan Keadilan Substantif dalam Perkara-Perkara Pidana. Alfabeta, Bandung.

Wulansari, Dewi, 2016, Hukum Adat Indonesia, Refika Aditama, Bandung.

\section{B. Artikel Jurnal}

Danil, Elwi, "Konstitusionalitas Penerapan Hukum Adat dalam Penyelesaian Perkara Pidana", Jurnal Konstitusi, Vol. 9, No. 3, September 2012.

Suartha, I Dewa Made, "Pergeseran Asas Legalitas formal ke Formal dan Material dalam Pembaruan Hukum Pidana Nasional", Jurnal Yustisia, Vol. 4, No. 1, Januari-April 2015.

Hasan, Ahmadi, "Penyelesaian Sengketa Melalui Upaya (Non-Litigasi) Menurut Peraturan Perundang-Undangan", Jurnal Al-Banjari, Vol. 5, No. 9, Januari-Juni 2007

Manarisip, Marco, "Eksistensi Pidana Adat dalam Hukum Nasional", Jurnal Lex Crimen, Vo. 1 No. 4, Oktober-Desember 2012.

Mujib, Misbahul. "Eksistensi Delik Adat dalam Kontestasi Hukum Pidana Indonesia”, Jurnal Supremasi Hukum, Vol. 2 No. 2, Desember 2013.

Situngkir, Danel Aditia, “Asas Legalitas dalam Hukum Pidana Nasional dan Hukum Pidana Internasional", Soematera Law Review, Vol. 1, No. 1, 2018.

Surya, Faizal Adi, "Tinjauan Mediasi Penal dalam Perspektif Hukum Adat dan Hukum Islam", Jurnal Jurisprudence, Vol. 5 No.2, September
2015

Sudrajat, Tedi, "Aspirasi Reformasi Hukum dan Penegakan Hukum Progresif melalui Media Hakim Perdamaian Desa", Jurnal Dinamika Hukum, Vol. 10 No. 3, September 2010.

Suhariyanto, Budi, "Eksistensi Pembentukan Hukum oleh Hakim dalam Dinamika Politik Legislasi di Indonesia", Jurnal Rechtsvinding, Vol. 4 No. 3, Desember 2015.

"Kedudukan Perdamaian Sebagai Penghapus Pemidanaan Guna Mewujudkan Keadilan Dalam Pembaruan Hukum Pidana", Jurnal Rechtsvinding, Vol. 5, No. 1, April 2017.

Zulfa, Eva Achjani, "Keadilan Restoratif dan Revitalisasi Lembaga Adat di Indonesia", Jurnal Kriminologi Indonesia, Vol. 6 No. II, Agustus 2010.

\section{Hasil Penelitian/Tugas Akhir}

Mulyadi, Lilik, 2010, Eksistensi Hukum Pidana Adat di Indonesia: Pengkajian Asas, Teori, Norma, Praktik dan Prosedurnya, Laporan Penelitian, Puslitbang Kumdil Mahkamah Agung, Jakarta.

\section{Makalah}

Din, Mohd., "Aspek Hukum Eksistensi Hukum Pidana Adat", Makalah, Seminar Penelitian dan Diskusi Terbatas tentang "Eksistensi Hukum Pidana adat di Indonesia: Pengkajian Asas, Teori, Praktik dan Prosedur" di hadapan hakim dari 4 lingkungan peradilan di wilayah Nangroe Aceh Darussalam, 29 Juni 2010

Loqman, Loebby, "Perkembangan Asas Legalitas dalam Hukum Pidana Indonesia", Makalah, Seminar Asas-Asas Hukum Pidana Nasional yang diselenggarakan oleh Badan Pembinaan Hukum Nasional Departemen Kehakiman dan Hak Asasi Manusia bekerjasama dengan Fakultas Hukum Universitas Diponegoro Semarang di Puri Suite Hotel Ciputra, Semarang, 26-27 April 2004. 
E. Internet

AchjaniZulfa, Eva, "EksistensiPeradilanAdat dalam Sistem Hukum Pidana Indonesia",http:// bphn.go.id/data/documents/lampiran_ makalah_dr.eva_achjani,_sh.,mh.pdf.

\section{F. Peraturan Perundang-undangan}

Undang-Undang Dasar Negara Republik Indonesia Tahun 1945.

Ketetapan Majelis Permusyawaratan Rakyat Sementara Nomor 11/MPRS/1960 tentang Garis-garis Besar Pola Pembangunan Nasional Semesta Berencana Tahapan Pertama 1961-1969.

Undang-Undang Darurat Nomor 1 Tahun 1951 tentang Tindakan-Tindakan Sementara untuk Menyelenggarakan Kesatauan Susunan Kekuasaan dan Acara Pengadilan-Pengadilan Sipil (Lembaran Negara Republik Indonesia Tahun 1951 Nomor 9. Tambahan Lembaran Negara Republik Indonesia Nomor 81).

Undang-Undang Nomor 19 Tahun 1964 tentang Ketentuan-Ketentuan Pokok Kekuasaan Kehakiman (Lembaran Negara Republik
Indonesia Tahun 1964 Nomor 107. Tambahan Lembaran Negara Republik Indonesia Nomor 2699).

Undang-Undang Nomor 1 Tahun 1974 tentang Perkawinan (Lembaran Negara Republik Indonesia Tahun 1974 Nomor 1. Tambahan Lembaran Negara Republik Indonesia Nomor 3019).

Undang-Undang Nomor 39 Tahun 1999 tentang Hak Asasi Manusia (Lembaran Negara Republik Indonesia Tahun 1999 Nomor 165. Tambahan Lembaran Negara Republik Indonesia Nomor 3886).

Undang-Undang Nomor 48 Tahun 2009 tentang Kekuasaan Kehakiman (Lembaran Negara Republik Indonesia Tahun 2009 Nomor 157. Tambahan Lembaran Negara Republik Indonesia Nomor 5076).

\section{G. Dokumen Lain}

Rancangan Kitab Undang-Undang Hukum Pidana versi Tahun 2015. 